ISSN: 1858-4837; E-ISSN: 2598-019X

Volume 17, Nomor 1 (2022),

https://jurnal.uns.ac.id/region

DOI: 10.20961/region.v17i1.32362

\title{
Penentuan variabel prioritas perkembangan hunian vertikal Kota Balikpapan berdasarkan preferensi pemerintah
}

\author{
Determining priority variable of Balikpapan vertical residence development \\ based on Local Government preference
}

\author{
P B Assidiq ${ }^{1}$, F Nurrahman ${ }^{1}$, dan U Sholikah ${ }^{2}$ \\ ${ }^{1}$ Program Studi Perencanaan Wilayah dan Kota, Jurusan Teknologi Sipil dan \\ Perencanaan, Institut Teknologi Kalimantan \\ 2Program Studi Teknik Lingkungan, Jurusan IImu Kebumian dan Lingkungan, Institut \\ Teknologi Kalimantan
}

Corresponding author's email: x1prayudi@gmail.com

\begin{abstract}
Abstrak. Pertumbuhan jumlah penduduk di Kota Balikpapan diproyeksikan mencapai 833.761 jiwa pada tahun 2032. Pada tahun 2014 angka kebutuhan hunian di Provinsi Kalimantan Timur mencapai 239.964 unit hunian. Penghuni rumah susun di Kota Balikpapan hanya sebesar $75 \%$ dari total 595 unit hunian. Adanya tumpang tindih kebijakan antara Peraturan Daerah Nomor 7 Tahun 2011 tentang Rumah Susun tidak relevan lagi dengan dokumen Rencana Tata Ruang Wilayah Kota Balikpapan. Penelitian ini bertujuan untuk menentukan faktor prioritas berdasarkan preferensi pemerintah menggunakan teknik analisis Analytical Hierarchy Process (AHP). Analisis AHP menghasilkan faktor dan variabel prioritas berdasarkan preferensi pemerintah yaitu faktor prasarana dengan variabel jaringan air bersih, faktor hukum dengan variabel kesesuaian penggunaan lahan dan faktor kepemilikan dengan variabel sistem sewa.
\end{abstract}

Kata Kunci: AHP; Faktor Prioritas; Hunian Vertikal

\begin{abstract}
The population in Balikpapan City by 2032 is predicted to reach 833,761 people. In 2014 the number of residential needs in East Kalimantan reached 239,964 residential units. Residents of condominium in Balikpapan City is $75 \%$ of the total 595 residential units. The overlapping policy between Regional Regulation No. 7 of 2011 concerning condominium is no longer relevant to the Balikpapan City's Masterplan Document. This study was designed to determining priority factor of Balikpapan's
\end{abstract}

Received: July 17, 2019; Accepted: April 20, 2020; Available online: January 31, 2021

Copyright @ 2022, REGION: Jurnal Pembangunan Wilayah dan Perencanaan Partisipatif 
vertical residence development based on local government preference using Analytical Hierarchy Process (AHP) method. AHP analysis produces priority factors and variables based on government preferences, namely infrastructure factors with clean water network variable, legal factors with land-use suitability variable, and ownership factors with rental system variable.

Keywords: AHP; Priority Factor; Vertical Residential

\section{Pendahuluan}

Kota Balikpapan merupakan salah satu kota yang terdapat di Provinsi Kalimantan Timur dengan luasan sebesar $50.330 \mathrm{~km}^{2}$ yang terbagi menjadi 6 kecamatan [1]. Pada tahun 2011 jumlah penduduk Kota Balikpapan sebesar 572.184 jiwa meningkat pada tahun 2017 sebesar 636.012 jiwa. Jumlah penduduk Kota Balikpapan terus akan meningkat pada tahun 2032 diproyeksikan mencapai angka 833.761 jiwa [1]. Peningkatan jumlah penduduk yang terjadi pada umumnya diakibatkan oleh beberapa faktor antara lain pertumbuhan penduduk alamiah yang dapat dihitung dari selisih antara jumlah kelahiran dan jumlah kematian, migrasi yang dilakukan oleh masyarakat pedesaan ke perkotaan dan perubahan wilayah pedesaan yang menjadi daerah perkotaan [2].

Fenomena pertumbuhan jumlah penduduk dapat mendorong kegiatan alih fungsi lahan untuk mengatasi berbagai permasalahan khususnya pada sektor perumahan dan permukiman, yaitu pemenuhan kebutuhan perumahan atau backlog [3]. Pertumbuhan jumlah penduduk tidak sebanding dengan pertumbuhan hunian. Target backlog nasional pada Tahun 2019 sebesar 5,4 juta tidak dapat dicapai, karena pada kenyataannya kekurangan jumlah hunian mencapai 7,6 juta [4,5]. Badan Lingkungan Hidup Kota Balikpapan [6] mengemukakan bahwa terdapat perubahan peruntukan kawasan hutan sebesar 1930,30 Ha yang digunakan untuk kawasan permukiman. Untuk menekan laju alih fungsi lahan permukiman sekaligus alternatif mengatasi backlog hunian pada kawasan berkepadatan tinggi, Pemerintah Kota Balikpapan juga menjalankan strategi hunian vertikal.

Pertumbuhan hunian vertikal di Kota Balikpapan setiap tahun mengalami peningkatan. Pada tahun 2018 terdapat 13 unit hunian vertikal di Kota Balikpapan. Hunian vertikal yang terdapat di Kota Balikpapan antara lain Rusunawa Damai Beriman, Rusunawa KM 7, Rusunawa Manggar, Rusunawa Perusda, Rusunawa Perusda 2, Rusunawa Sepinggan, Rusunawa Sepinggan 2, Rusunawa Siaga dan Rusunawa Somber, sedangkan 4 hunian vertikal lainnya dikelola oleh pihak swasta antara lain Apartemen Malibu, Apartemen Pertamina, Ruby Tower Apartemen dan Pentapolis Apartemen [7].

Pembangunan hunian vertikal rusunawa di Kota Balikpapan dimulai pada tahun 1994 - 1995, yaitu Rusunawa Damai. Selanjutnya, pembangunan rusunawa di Kota Balikpapan mulai dibangun lagi pada tahun 2008 - 2017 dengan total 8 rusunawa, antara lain Rusunawa Manggar, Rusunawa Sepinggan I dan II, Rusunawa Kilometer 7, Rusunawa Siaga, Rusunawa Perusda I dan II, dan yang terakhir pada tahun 2016 - 2017 adalah Rusunawa Somber [7]. Pada 
tahun 2018 total unit hunian rusunawa sebanyak 595 unit, namun dari total unit yang tersedia terdapat $25,38 \%$ unit hunian rusunawa yang belum dihuni sehingga pemanfaatan hunian rusunawa belum optimal [7].

Terdapat berbagai macam dampak dari pertumbuhan jumlah apartemen, salah satunya adalah terciptanya kesenjangan sosial di sekitar lokasi apartemen tersebut. Masyarakat sekitar lokasi apartemen juga harus menyesuaikan fungsi bangunan sehingga dapat mempengaruhi aspek fisik dan ekonomi dari kawasan tersebut [8]. Sedangkan Agmelina \& Ariastita [9] mengidentifikasi dampak yang terjadi akibat pertumbuhan jumlah apartemen khususnya di Kota Surabaya adalah penurunan kinerja jalan dikarenakan peningkatan volume lalu lintas.

Pemerintah Kota Balikpapan mengantisipasi permasalahan yang timbul akibat pertumbuhan jumlah hunian vertikal apartemen dengan membuat beberapa peraturan daerah yang mengatur seputar hunian vertikal antara lain Peraturan Daerah Nomor 12 Tahun 2012 Tentang Rencana Tata Ruang Wilayah Kota Balikpapan Tahun 2012 - 2032, Peraturan Daerah Nomor 3 Tahun 2016 Tentang Bangunan Gedung dan Peraturan Daerah Nomor 7 Tahun 2011 Tentang Rumah Susun $[10,11]$. Namun, masih terdapat permasalahan pembangunan hunian vertikal di Kota Balikpapan seperti yang terjadi pada proses pembangunan Balikpapan City Center yang terletak di Kelurahan Karang Jati. Pada tahun 2013, Izin Mendirikan Bangunan (IMB) Balikpapan City Center telah terbit dengan Nomor 0430/DTKP/BTg/MKS namun pembangunan Balikpapan City Center belum selesai hingga tahun 2018.

Permasalahan terkait tumpang tindih regulasi yang mengatur terkait rumah susun dapat dilihat pada Peraturan Daerah Kota Balikpapan Nomor 12 Tahun 2012 Tentang Rencana Tata Ruang Wilayah Kota Balikpapan Tahun (RTRW) 2012 - 2032 dengan Peraturan Daerah Nomor 7 Tahun 2011 Tentang Rumah Susun [10,11]. Pada dokumen RTRW disebutkan pada pasal 50 ayat 5 bahwa ketentuan pengembangan hunian vertikal terdapat pada kawasan perumahan kepadatan tinggi yang terdapat di Kecamatan Balikpapan Kota, Kecamatan Balikpapan Selatan, Kecamatan Balikpapan Barat, dan Kecamatan Balikpapan Tengah. Namun, pada Peraturan Daerah Kota Balikpapan Nomor 7 Tahun 2011 Tentang Rumah Susun pasal 5 [11] belum dijelaskan terkait penetapan zonasi dan lokasi perencanaan pembangunan rumah susun sehingga penetapan lokasi rumah susun ditetapkan oleh Wali Kota Balikpapan dengan persetujuan DPRD Kota Balikpapan. Berdasarkan data, fenomena, dan fakta yang telah dipaparkan, maka diperlukan sebuah studi tentang faktor prioritas yang menjadi pertimbangan dalam pengembangan hunian vertikal di Kota Balikpapan.

\section{Metode}

\subsection{Pendekatan penelitian}

Pendekatan yang digunakan dalam penelitian adalah pendekatan rasionalistik, yaitu suatu pendekatan penelitian yang memiliki jenis atau karakteristik penggunaan rasio dalam menyusun kerangka teoritik dan memberikan makna (interpretasi) hasil penelitian. Menurut ilmu rasionalisme, paham filsafat yang mengatakan bahwa akal adalah alat terpenting dalam 
memperoleh pengetahuan. Rasionalisme mengajarkan bahwa pengetahuan diperoleh dengan cara berpikir logis. Alat berpikir itu adalah kaidah-kaidah logis atau logika [12].

\subsection{Lokasi penelitian}

Ruang lingkup wilayah dalam penelitian ini adalah hunian vertikal yang terdapat di Kota Balikpapan yang terdiri dari 6 kecamatan antara lain Kecamatan Balikpapan Utara, Balikpapan Timur, Balikpapan Selatan, Balikpapan Barat, Balikpapan Tengah dan Balikpapan Kota. Berikut merupakan peta ruang lingkup wilayah penelitian yang dapat dilihat pada Gambar 1.

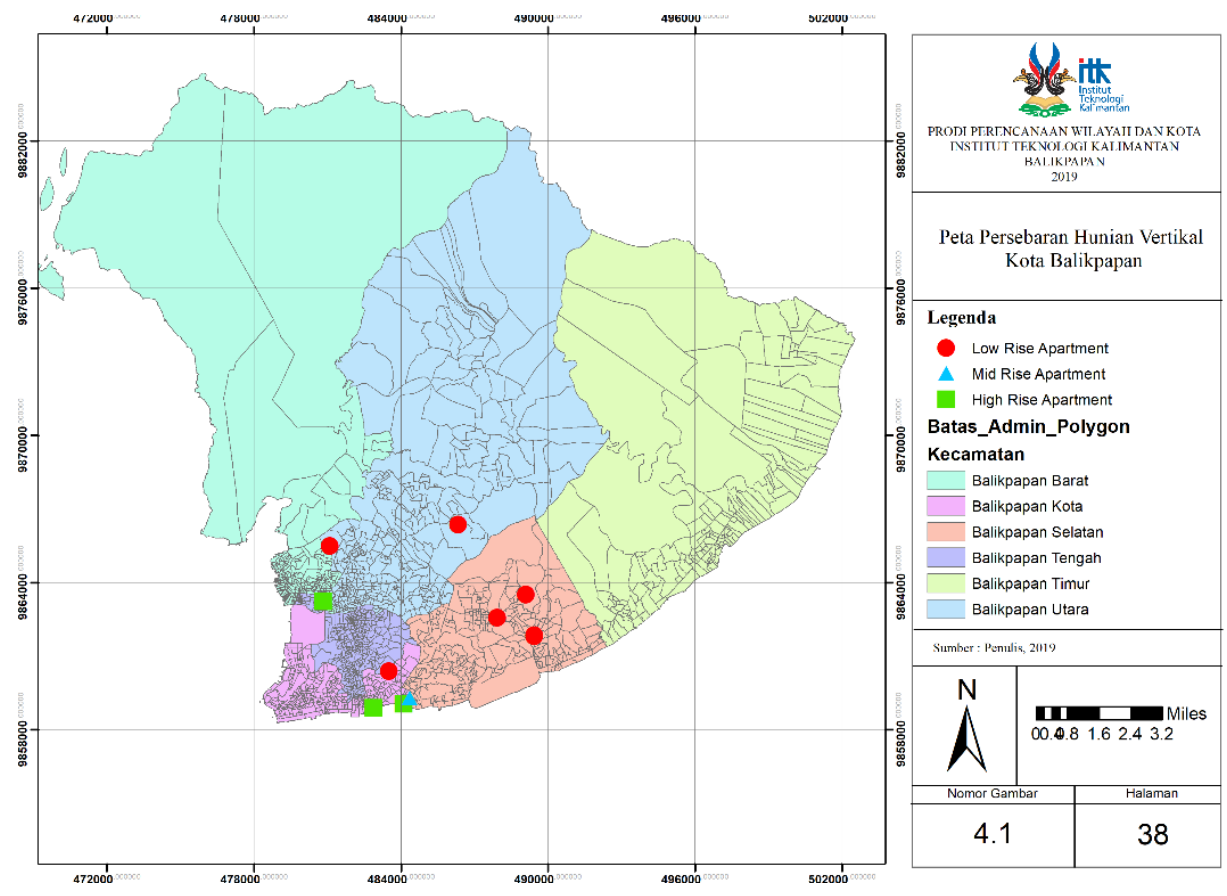

Gambar 1. Peta persebaran hunian vertikal Kota Balikpapan.

\subsection{Teknik pengumpulan data}

Pada penelitian yang akan dilakukan, adapun metode pengumpulan data yang digunakan oleh peneliti sebagai berikut.

2.3.1. Wawancara (in-depth interview). Menurut Esterberg dalam Sugiyono [13], wawancara merupakan kegiatan yang dilakukan guna mendapatkan informasi secara langsung dengan cara mengajukan beberapa pertanyaan kepada narasumber. Teknik wawancara seperti ini lebih bersifat terbuka dengan melakukan eksplorasi terhadap faktor-faktor yang dapat mempengaruhi perkembangan hunian vertikal berdasarkan pendapat yang dikemukakan oleh narasumber.

2.3.2. Data sekunder. Pengumpulan data sekunder dilakukan dengan cara mencari data dari pihak ketiga, dalam hal ini adalah instansi/lembaga terkait seperti Dinas Perumahan dan Permukiman, Unit Pelaksana Teknis Rumah Susun Sederhana Sewa (UPT Rusunawa), Dinas 
Penanaman Modal dan Perizinan Terpadu. Data tersebut biasanya dapat berupa dokumen, data atau arsip terkait perkembangan hunian vertikal di Kota Balikpapan.

\subsection{Teknik analisis data}

2.4.1. Analisis Analytical Hierarchy Process (AHP). Faktor dan variabel yang telah terkumpul kemudian digunakan sebagai input data untuk analisis penentuan prioritas pengaruh perkembangan hunian vertikal di Kota Balikpapan dengan metode Analytical Hierarchy Process (AHP) menggunakan software Super Decisions. Hasil dari analisis ini merupakan bobot setiap variabel dari faktor prioritas. Faktor dan variabel disusun secara sistematis membentuk pohon hirarki seperti pada bagan yang dapat dilihat pada Gambar 2.

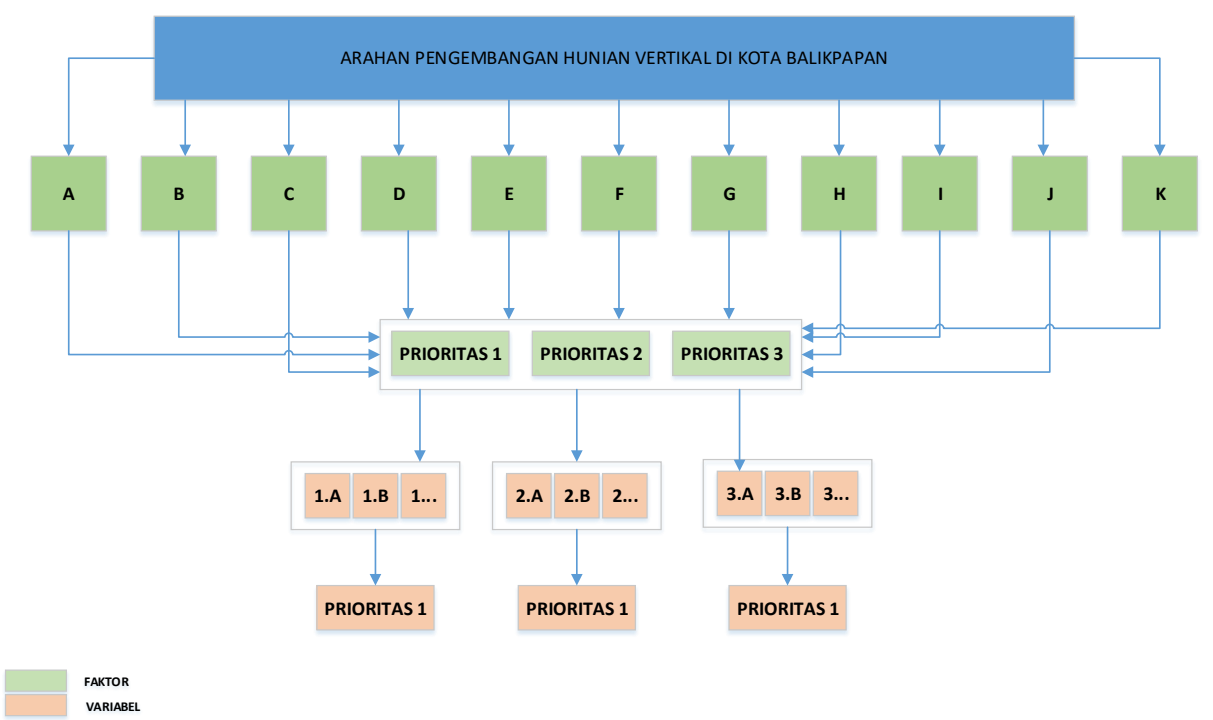

Gambar 2. Pohon hierarki arahan pengembangan hunian vertikal di Kota Balikpapan.

\section{Hasil penelitian dan pembahasan}

\subsection{Penentuan faktor prioritas perkembangan hunian vertikal di Kota Balikpapan}

3.1.1. Penentuan bobot faktor berdasarkan analisis AHP. Berdasarkan hasil analisis AHP yang telah dilakukan menggunakan software Super Decisions, maka dapat diketahui ketiga faktor yang memiliki bobot tertinggi, antara lain faktor prasarana, hukum dan kepemilikan. Berikut adalah matriks perbandingan yang dihasilkan dapat dilihat pada Tabel 1.

Berdasarkan hasil dari rata-rata nilai matriks perbandingan dari keempat stakeholder maka dapat dilihat bahwa faktor prasarana merupakan faktor yang memiliki tingkat kepentingan tertinggi dikarenakan nilai dari matriks perbandingan $>1$ jika dipasangkan terhadap semua faktor kecuali faktor hukum. Faktor prasarana, 6.44 kali lebih penting jika dipasangkan dengan faktor lingkungan dan ketika dipasangkan dengan faktor lokasi, faktor prasarana memiliki nilai 5.21 kali lebih penting. Namun, faktor prasarana memiliki nilai $<1$ saat dipasangkan dengan 
faktor hukum. Hal ini dapat diartikan bahwa faktor prasarana tidak lebih penting ketika dipasangkan dengan faktor hukum karena memiliki nilai matriks perbandingan sebesar 0.93. Berdasarkan nilai matriks perbandingan di atas, maka faktor prasarana menjadi faktor dengan bobot tertinggi jika dibandingkan dengan sepuluh faktor lainnya dengan nilai sebesar 0.16 sesuai dengan grafik yang terdapat pada Gambar 3.

Tabel 1. Matriks perbandingan antar faktor.

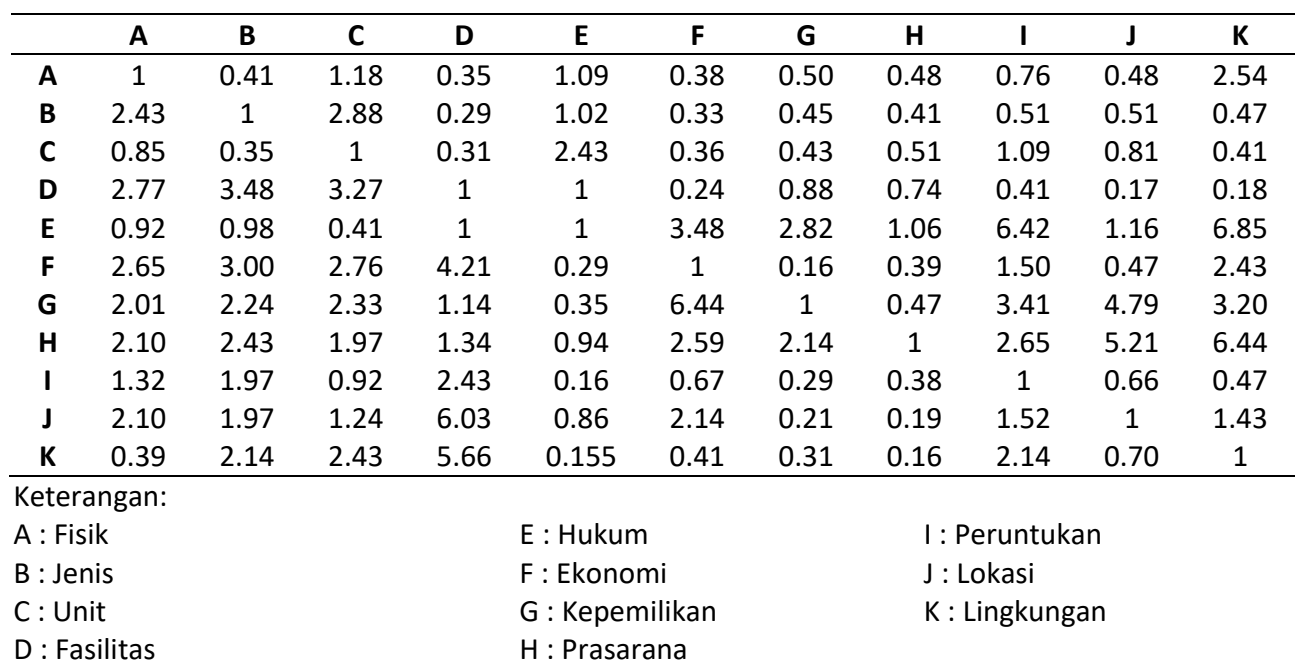

Kemudian faktor hukum berdasarkan rata-rata nilai matriks perbandingan dari keempat stakeholder merupakan faktor dengan tingkat kepentingan urutan kedua. Sedangkan, faktor hukum memiliki tingkat kepentingan 6.85 kali lebih penting ketika dipasangkan dengan faktor lingkungan. Namun, faktor hukum tidak lebih penting jika dipasangkan terhadap faktor fisik, unit apartemen dan faktor jenis apartemen dikarenakan masing-masing nilai kepentingan $<1$. Ketika faktor hukum dipasangkan dengan faktor fasilitas, maka nilai kepentingan dari kedua faktor dinilai sama oleh keempat stakeholder dengan nilai rata-rata matriks perbandingan $=1$. Berdasarkan nilai matriks perbandingan di atas, maka faktor hukum menjadi faktor dengan bobot tertinggi kedua jika dibandingkan dengan sepuluh faktor lainnya dengan nilai sebesar 0.15 sesuai dengan grafik yang terdapat pada Gambar 3.

Faktor kepemilikan merupakan faktor dengan tingkat kepentingan urutan ketiga berdasarkan rata-rata nilai matriks perbandingan. Faktor kepemilikan memiliki nilai rata-rata matriks perbandingan $>1$ terhadap 8 faktor lainnya. Faktor kepemilikan memiliki nilai kepentingan tertinggi ketika dipasangkan terhadap faktor ekonomi dengan nilai rata-rata sebesar 6.44 kali lebih penting. Namun, faktor kepemilikan tidak lebih penting ketika dipasangkan terhadap faktor hukum dan prasarana dengan masing-masing nilai rata-rata matriks perbandingan sebesar 0.35 dan 0.46. Berdasarkan nilai matriks perbandingan di atas, maka faktor kepemilikan memiliki bobot tertinggi ketiga dari total sepuluh faktor lainnya dengan nilai bobot sebesar 0.144 sesuai dengan grafik yang terdapat pada Gambar 3. 
Berikut adalah nilai bobot dari masing-masing faktor yang telah didapatkan berdasarkan hasil analisis Analytical Hierarchy Process menggunakan software Super Decisions.

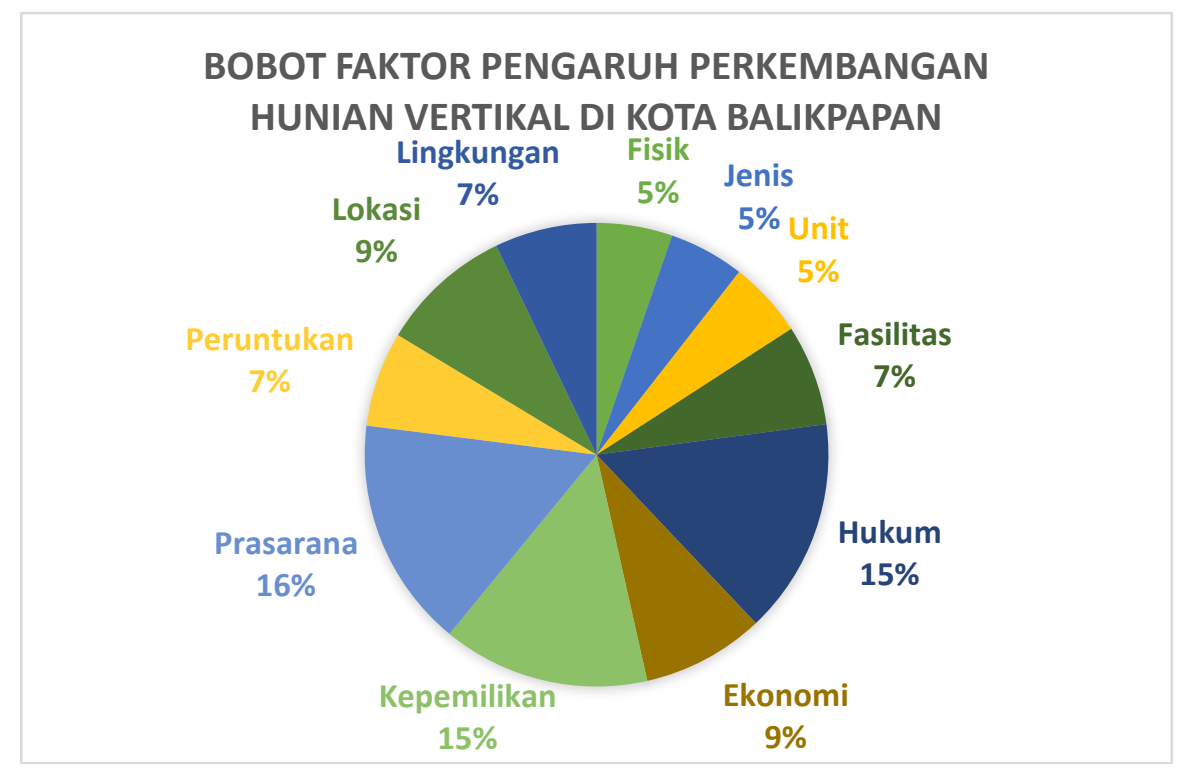

Gambar 3. Bobot faktor pengaruh perkembangan hunian vertikal di Kota Balikpapan.

3.1.2. Penentuan bobot variabel pada faktor prasarana berdasarkan analisis AHP. Faktor prasarana didapatkan sebagai faktor dengan bobot nilai tertinggi setelah mendapatkan faktor prioritas. Kemudian dilakukan penentuan bobot variabel tertinggi dari setiap variabel pada faktor prasarana, variabel yang menjadi input adalah variabel jaringan listrik, jaringan gas, jaringan telepon, jaringan air bersih, dan jaringan drainase. Berikut adalah tabel hasil dari matriks perbandingan setiap variabel yang terdapat pada faktor prasarana yang tertera pada Tabel 2.

Tabel 2. Matriks perbandingan antar variabel pada faktor prasarana.

\begin{tabular}{cccccc}
\hline & Listrik & Gas & Telepon & Air Bersih & Drainase \\
\hline Listrik & 1 & 6.30 & 8.45 & 0.27 & 1.07 \\
Gas & 0.16 & 1 & 3.01 & 0.36 & 0.35 \\
Telepon & 0.12 & 0.33 & 1 & 0.11 & 0.70 \\
Air & 3.71 & 2.76 & 8.45 & 1 & 6.85 \\
Bersih & & & & & \\
Drainase & 0.94 & 2.94 & 1.43 & 0.14 & 1 \\
\hline
\end{tabular}

Berdasarkan matriks perbandingan di atas, dapat dilihat bahwa variabel jaringan air bersih memiliki tingkat kepentingan lebih penting dari setiap variabel yang terdapat di faktor prasarana. Variabel jaringan air bersih memiliki tingkat kepentingan 3.71 kali lebih penting ketika dipasangkan dengan variabel jaringan listrik. Sedangkan ketika dipasangkan dengan 
variabel jaringan gas, variabel jaringan air bersih memiliki tingkat kepentingan 2.76 lebih penting dari variabel jaringan gas. Nilai kepentingan tertinggi variabel jaringan air bersih didapatkan ketika dipasangkan dengan variabel jaringan telepon. Nilai kepentingan variabel jaringan air bersih yang didapatkan adalah sebesar 8.45 kali lebih penting dari variabel jaringan telepon. Jaringan air bersih juga memiliki tingkat kepentingan sebesar 6.85 kali lebih penting dari variabel jaringan drainase. Berdasarkan dari matriks perbandingan di atas, maka didapatkan nilai bobot dari setiap variabel pada faktor prasarana sebagai berikut (lihat Gambar 4).

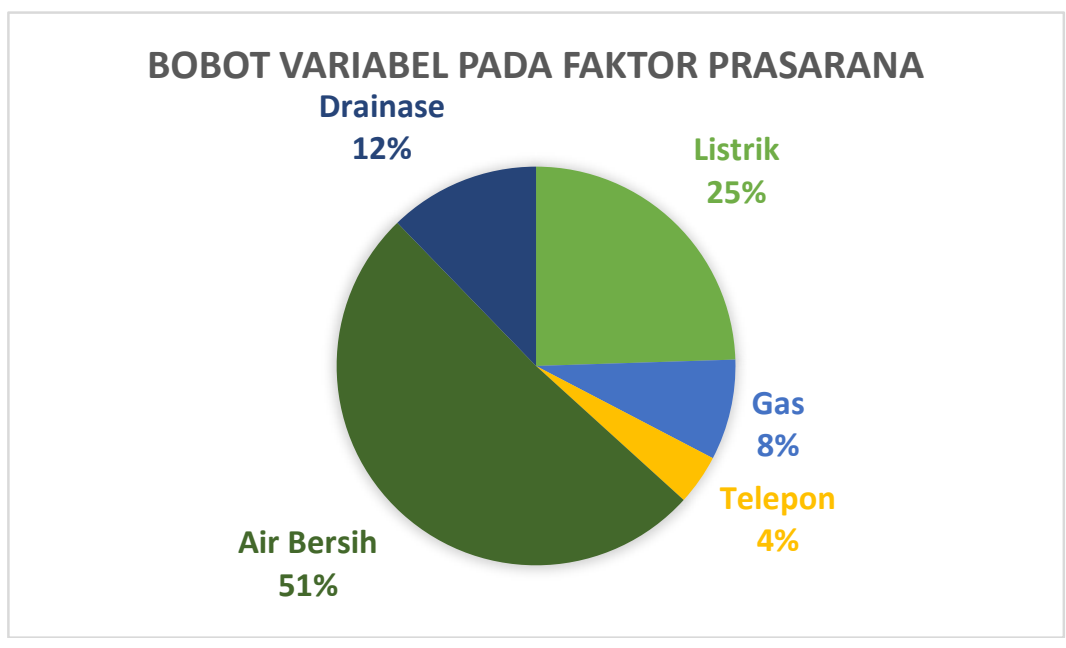

Gambar 4. Bobot variabel pada faktor prasarana.

Berdasarkan grafik di atas, variabel jaringan air bersih memiliki bobot tertinggi dengan nilai sebesar 0.51. Kemudian dilanjutkan dengan variabel jaringan listrik dengan nilai bobot sebesar 0.24 , variabel jaringan drainase sebesar 0,12 , variabel jaringan drainase sebesar 0.08 dan dengan bobot terkecil adalah variabel jaringan telepon sebesar 0.04. Maka dapat disimpulkan pada faktor prasarana bahwa variabel yang memiliki bobot tertinggi atau diprioritaskan adalah variabel jaringan air bersih.

3.1.3. Penentuan bobot variabel pada faktor hukum berdasarkan analisis AHP. Faktor hukum didapatkan sebagai faktor dengan bobot nilai tertinggi kedua setelah faktor prasarana berdasarkan faktor prioritas dari setiap faktor. Kemudian dilakukan penentuan bobot variabel tertinggi dari setiap variabel, antara lain kesesuaian penggunaan lahan, kesesuaian area parkir, kesesuaian ketinggian bangunan, dan legalitas. Berikut adalah hasil dari matriks perbandingan setiap variabel yang terdapat pada faktor hukum tertera pada Tabel 3.

Tabel 3. Matriks perbandingan antar variabel pada faktor hukum.

\begin{tabular}{lrrrr}
\hline & Penggunaan Lahan & Area Parkir & Ketinggian Bangunan & Legalitas \\
\hline Penggunaan Lahan & 1 & 7.45 & 2.65 & 6.30 \\
Area Parkir & 0.13 & 1 & 2.24 & 0.41 \\
Ketinggian Bangunan & 0.38 & 0.44 & 1 & 0.41 \\
Legalitas & 0.16 & 2.43 & 2.43 & 1 \\
\hline Received: July 17, 2019; Accepted: April 20, 2020; Available online: January 31, 2021 & & 39
\end{tabular}

Copyright @ 2022, REGION: Jurnal Pembangunan Wilayah dan Perencanaan Partisipatif 
Berdasarkan matriks perbandingan di atas, maka dapat diketahui variabel dengan tingkat kepentingan tertinggi pada faktor hukum adalah kesesuaian penggunaan lahan. Hal ini dapat dilihat dari tingkat kepentingan variabel kesesuaian penggunaan lahan 7.45 kali lebih penting ketika dipasangkan dengan kesesuaian area parkir. Apabila dipasangkan dengan kesesuaian ketinggian bangunan, maka variabel kesesuaian penggunaan lahan memiliki tingkat kepentingan sebesar 2.65 kali lebih penting dari kesesuaian ketinggian bangunan dan 6.30 kali lebih penting dari variabel legalitas. Berikut adalah grafik bobot nilai dari setiap variabel yang terdapat pada faktor hukum yang telah didapat dari hasil analisis AHP menggunakan software Super Decisions (lihat Gambar 5).

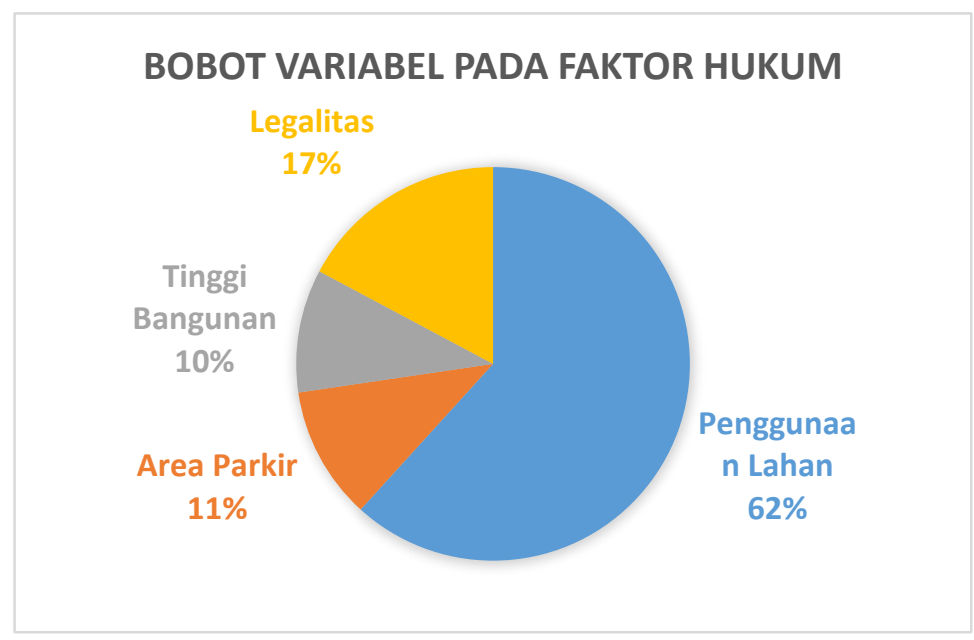

Gambar 5. Bobot variabel pada faktor hukum.

Berdasarkan grafik di atas, variabel yang memiliki bobot nilai tertinggi adalah variabel kesesuaian penggunaan lahan dengan bobot sebesar 0.61. Kemudian variabel legalitas memiliki bobot sebesar 0.17 dan dilanjutkan dengan variabel kesesuaian area parkir sebesar 0.11 serta variabel kesesuaian tinggi bangunan sebesar 0.1 sebagai variabel dengan bobot nilai terendah dari setiap variabel yang terdapat pada faktor hukum. Maka dapat ditarik kesimpulan bahwa variabel kesesuaian penggunaan lahan merupakan variabel dengan bobot tertinggi pada faktor hukum.

3.1.4. Penentuan bobot variabel pada faktor kepemilikan berdasarkan analisis AHP. Faktor kepemilikan didapatkan sebagai faktor dengan bobot nilai tertinggi ketiga setelah faktor prasarana dan faktor hukum berdasarkan faktor prioritas dari semua faktor. Kemudian dilakukan penentuan bobot variabel tertinggi dari setiap variabel, antara lain sistem sewa dan sistem jual-beli. Berikut adalah hasil dari matriks perbandingan antar variabel yang terdapat pada faktor kepemilikan

Tabel 4. Matriks perbandingan antar variabel pada faktor kepemilikan.

\begin{tabular}{ccc}
\hline & Sistem Sewa & Sistem Jual Beli \\
\hline Sistem Sewa & 1 & 7.45 \\
Sistem Jual Beli & 0.13 & 1 \\
\hline
\end{tabular}

Received: July 17, 2019; Accepted: April 20, 2020; Available online: January 31, 2021

Copyright $\odot$ 2022, REGION: Jurnal Pembangunan Wilayah dan Perencanaan Partisipatif 
Berdasarkan matriks perbandingan di atas, maka dapat diketahui dari keempat stakeholder memilih sistem sewa karena merupakan variabel yang memiliki kepentingan 7.45 kali lebih penting ketika dipasangkan dengan variabel sistem jual beli. Oleh karena itu, didapatkan nilai bobot dari masing-masing variabel yang terdapat di faktor kepemilikan sebagai berikut (lihat Gambar 6).

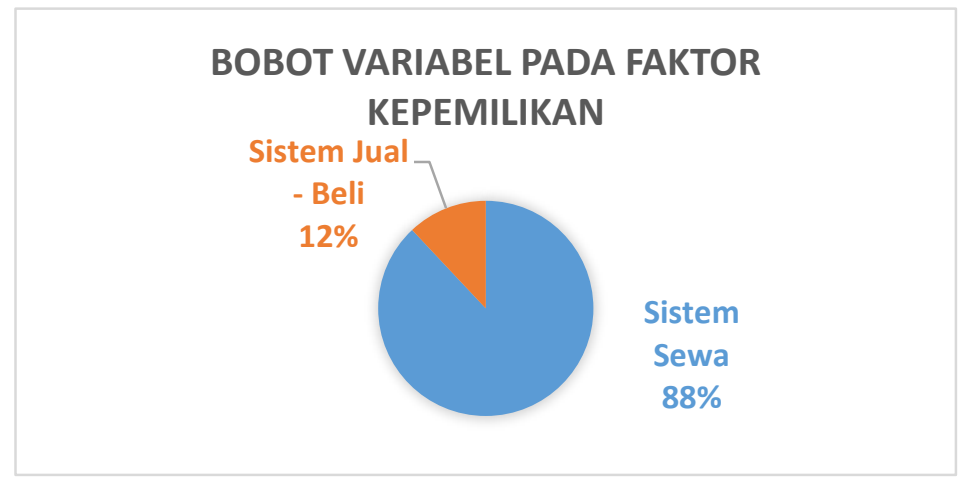

Gambar 6. Bobot variabel pada faktor kepemilikan.

\section{Kesimpulan}

Berdasarkan hasil analisis AHP dapat disimpulkan bahwa faktor yang memiliki bobot tertinggi atau prioritas, antara lain adalah faktor prasarana, faktor hukum dan faktor kepemilikan. Selanjutnya, dilakukan proses yang sama terhadap variabel dari setiap faktor prioritas sehingga mendapatkan variabel prioritas dari setiap faktor. Variabel prioritas dari faktor prasarana adalah variabel jaringan air bersih, variabel prioritas dari faktor hukum adalah variabel kesesuaian penggunaan lahan, dan variabel prioritas dari faktor kepemilikan adalah variabel sistem sewa.

\section{Referensi}

[1] Badan Pusat Statistik Kota Balikpapan. Kota Balikpapan Dalam Angka Tahun 20172017.

[2] Chotib. Urbanisasi dan Migrasi di Kota Depok Jawa Barat. Warta Demografi 2008;38:716.

[3] Murbaintoro T, Ma'arif MS, Sutjahjo SH, Saleh I. Model Pengembangan Hunian Vertikal Menuju Keberlanjutan. J Permukim 2009;4:72-87.

[4] Hutapea E. Per 8 Maret 2019, “Backlog” Rumah 7,6 Juta Unit. KompasCom 2019.

[5] Kementerian PPN/Bappenas. Peraturan Presiden RI No 2 Tahun 2015 tentang Rencana Pembangunan Jangka Menengah Nasional (RPJMN) 2015-2019 2014.

[6] Badan Lingkungan Hidup Kota Balikpapan. Buku Laporan Status Lingkungan Hidup Kota Balikpapan 2014. 2014.

[7] UPTD Rusunawa Kota Balikpapan. Data Rusunawa Kota Balikpapan 20182018.

[8] Fauzia R. Pengaruh Pembangunan Apartemen Solo Paragon Terhadap Kondisi Lingkungan Sekitarnya. Universitas Sebelas Maret, 2010.

[9] Agmelina EN, Ariastita PG. Faktor Pemilihan Lokasi Apartemen Metropolitan Area. J Tek ITS 2017;6:C491-5.

[10] Pemda Kota Balikpapan. Peraturan Daerah Kota Balikpapan Nomor 12 Tahun 2012 
Tentang Rencana Tata Ruang Wilayah Kota Balikpapan Tahun 2012-2032 2012. https://doi.org/10.1145/3132847.3132886.

[11] Pemda Kota Balikpapan. Peraturan Daerah Kota Balikpapan Nomor 7 Tahun 2011 tentang Rumah Susun 2011.

[12] Tafsir A. Filsafat umum : Akal dan hati sejak Thales sampai Capra. Bandung: PT. Remaja Rosdakarya; 2012.

[13] Sugiyono. Metode Penelitian Pendidikan: Pendekatan Kuantitatif, Kualitatif, dan RD. Bandung: Alfabeta; 2007. 